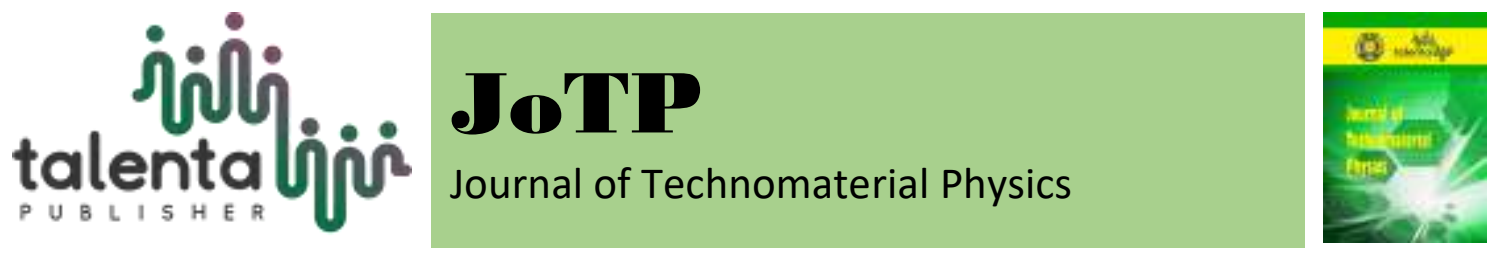

\title{
Model Program Processing of Fishbone Waste Transfer for the Application of Drinking Water Products and Test Characterization
}

\author{
M. Sontang Sihotang ${ }^{1}$, Dara Aisyah Ali Puteh ${ }^{2}$, Kerista Sebayang ${ }^{3}$ and \\ Lukman Hakim ${ }^{4}$ \\ ${ }^{1,3,4}$ Physics Study Program, Faculty of Mathematics and Natural Science, Universitas Sumatera Utara \\ ${ }^{2}$ Department of Public Administration, Faculty of Social and Politics, Universitas Sumatera Utara
}

\begin{abstract}
The fish bone waste treatment program for the application of useful products, specifically as a natural ingredient of the drinking water filter. This program works with coastal communities in terms of providing raw materials. This program is a social innovation from the transfer of knowledge of the university's inventors to the coastal communities, in the aim to maintain and improve the cleanliness of the environment, which is then applied for the purpose of developing a water filter system. The contribution of this organic product is useful for Small, Micro \& Medium Enterprises engaged in the production of food and beverages, as well as donations for cosmetic and health products to industries, as well as donations to policy development, through the application of environmental physics and science development to product development, precommercialization and commercialization (social engineering \& manufacturing). The involvement of coastal communities in utilizing their waste is to achieve the empowerment of coastal communities, emphasizing community involvement to learn and cooperate for future development goals. Prior to the formation of this program, the community who failed to take care of its waste often had the waste dumped into the sea, rivers and garbage collection sites. The disposal causes the form of pollution problems that invite various dangerous diseases and cause the community environment to be clean, smelly and diseased. The results of the research have been done, Fish bone waste can be processed to be a product of water filter system resulting from fish processing industry, which contains high calcium. Fish bones are very rich in calcium that is needed by the human body, because the main elements of fish bones are calcium and phosphorus. The use of fish bone calcium is widespread such as overcoming coastal pollution and other environments in the disposal of heavy metals such as Zinc $(\mathrm{Zn})$, Copper $(\mathrm{Cu})$, Lead $(\mathrm{Pb})$, and Iron $(\mathrm{Fe})$.
\end{abstract}

Keyword:processing, waste, innovation, filter, water.

Received 23 November 2018 | Revised [23 January 2019] | Accepted [28 February 2019]

\section{Introduction}

From the research conducted on 50 people in coastal community of Kuala Terengganu, Malaysia, it is found that there has no public socialization ever conducted to educate people about the benefits of fish bone waste $(86.7 \%)$. People there also do not know the use of fish

*Corresponding author at: Jl. Bioteknologi No.1 Kampus USU, Medan 20155, Indonesia,

E-mail address: muhammad.sontang@usu.ac.id 
bone waste that they sell to the aquaculture entrepreneurs who freely collect the waste all this time $(63.3 \%)$ [1-4]. Based on the survey, the researcher conducted an analytical study "need assessment" to the fisherman community, which results produce the organic water filter for coastal residents [5-11]. The study uses social innovation model via waste management technology.

There are approximately 119 million people in Indonesia do not have access to clean water [1214]. Only $20 \%$ people are able to use clean water for their daily activities, mainly those who reside in the cities. This means that there are still $82 \%$ of Indonesian people who are forced to use the unhealthy water. The percentage of clean water access in rural areas of Indonesia is lower than some neighbor countries such as Malaysia.

Indonesia government has conducted numerous coaching programs in regards to water treatment in all provinces and some rural areas in Indonesia. But the crisis of clean water is still found, especially in the remote areas. The quality of water supply in Indonesia is declining as the water is increasingly polluted due to the outdated system of water filter. The increased pollution in water sources and rivers cause a slump of quality in water supply, aside from other pollutants such as corrosion, dust, sand etc inside the old asbestos pipes.

Through the study in this paper, there is one innovation to increase the quality of drinking water. This study is conducted as the responsibility of the University, as a contribution to the public health office and National Food and Drugs Agency to ensure the availability of water, also as the standard and guidelines for water operator in supplying water [15-20].

The use of water filter and bottled water among Indonesian customers are considered competitive in terms of filtering the organic alkaline content, the halalness and the wholesomeness. The tight standard procedure hence does not raise issues in public, for example the issue that carbons are made of pork bones.

\section{Materials and Methods}

The source of filter media is the calcium collected from fish bone waste from East Coast Malaysia. The fish bone waste was obtained from the remaining process of cracker factory at Kuala Terengganu Malaysia. The fish bones were cleaned with water and then boiled and dried. The bones were then mashed with a blender, and grinded to powder at Kuala Terengganu. Afterwards, powder was taken to SIRIM Berhad Shah Alam Malaysia to be heated in a furnace, producing fish bone calcium. While the water sample for water quality test was taken from the pond at Universiti Malaysia Terengganu (UMT) Malaysia, also from Tambunan Langkat Village, North Sumatra. The obtained fish bone powder was then characterized by using SEM EDAX and AAS at the research laboratory of Universiti Kebangsaan Malaysia (UKM), Internasional Islamic Universiti Malaysia (IIUM), Universiti Putra Malaysia (UPM) and SIRIM 
Berhad Malaysia. The X-RF test towards the fish bone sample was done at BATAN Puspiptek Serpong Tangerang Banten and research laboratory at Faculty of Pharmacy of Universitas Sumatera Utara (USU).

\section{Result and Discussion}

From the AAS (Atomic Absorption Spectroscopy) test, it is stated in table 1 and 2 that Calcium Hydroxyapatite (CaHAp) from fish bones is effective to the removal of Heavy Metal; Zinc ( $\mathrm{Zn}$ ) and Lead $(\mathrm{Pb})$, each by $103 \%$ and $95 \%$, the Activated Carbon (AC) of fish bones is effective to the removal of copper $(\mathrm{Cu})$ by $107 \%$, while the Activated Carbon and Hydroxiapatite (AC+HAp) affect the decrease of Zinc by $80 \%$.
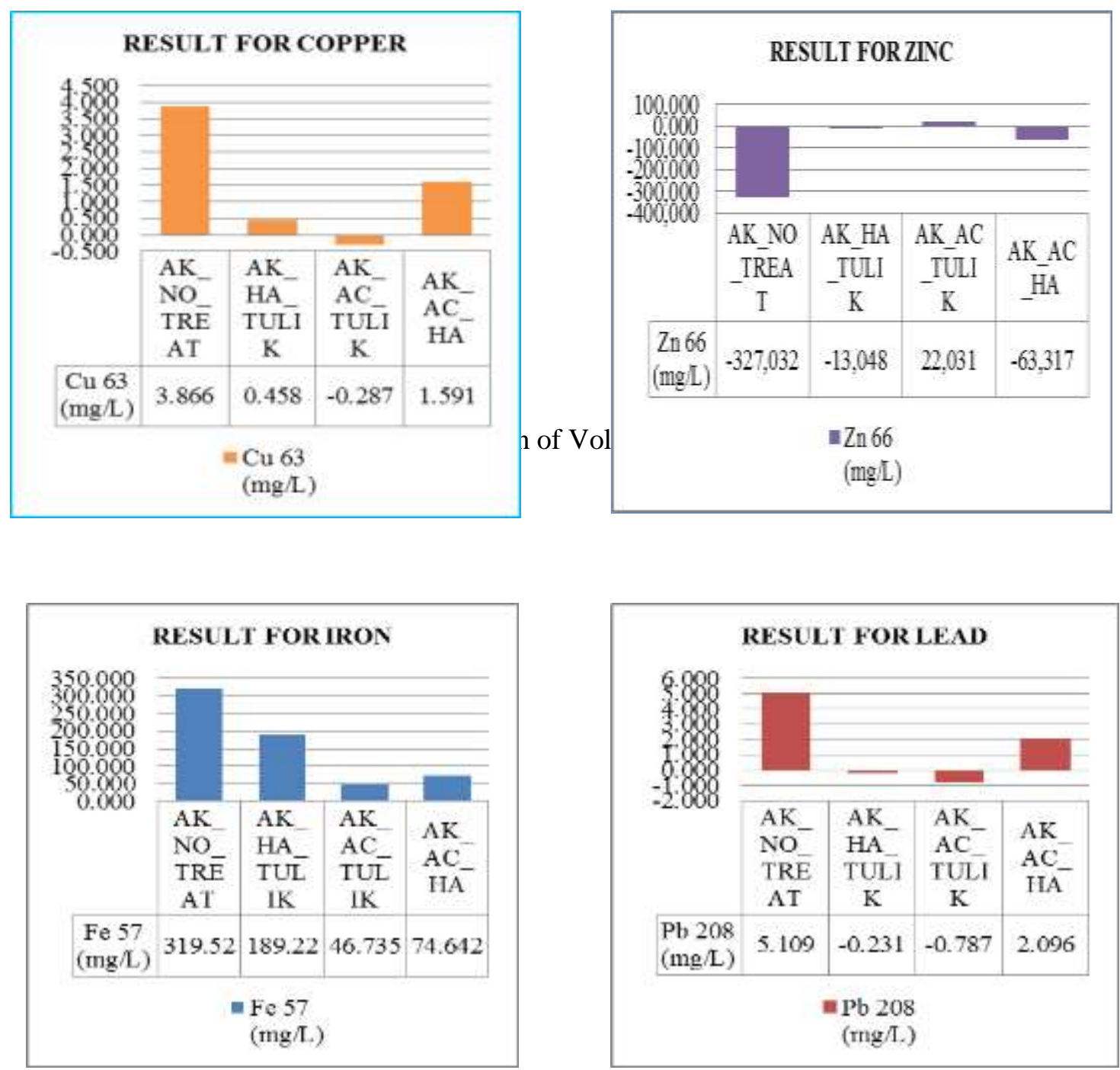

Figure 1. The Treatment of Hydroxyapatite (HAp) and Activated Carbon (AC) from Fish Bones in decreasing the content of Heavy Metal (a). Copper (Cu), (b). Zinc (Zn) (c). Iron (Fe) and (d). Lead $(\mathrm{Pb})$. 
Table 1.The analysis of Hydroxyapatite Treatment (HAp) and Activated Carbon (AC) from

Fish Bones in decreasing the content of Heavy Metal: Copper $(\mathrm{Cu})$, Zinc $(\mathrm{Zn}), \operatorname{Iron}(\mathrm{Fe})$ and Lead $(\mathrm{Pb})$.

\begin{tabular}{|c|c|c|c|c|c|c|c|c|c|}
\hline \multirow{2}{*}{ No. } & \multirow{2}{*}{ Treatment } & \multicolumn{2}{|c|}{$\mathrm{Cu}$ (Copper) } & \multicolumn{2}{|c|}{ Zn (Zinc) } & \multicolumn{2}{|c|}{$\mathrm{Fe}$ (Iron) } & \multicolumn{2}{|c|}{$\mathrm{Pb}($ Lead $)$} \\
\hline & & Rate & $(\%)$ & Rate & $(\%)$ & Rate & $(\%)$ & Rate & $(\%)$ \\
\hline 1 & Treatment No & \multicolumn{2}{|c|}{3.866} & \multicolumn{2}{|c|}{-327.032} & \multicolumn{2}{|c|}{319.528} & \multicolumn{2}{|c|}{5.109} \\
\hline 2 & HAp of Fish Bones & 0.458 & 88 & -13.048 & 103 & 189.220 & 40 & -0.231 & 95 \\
\hline 3 & AC of Fish Bones & -0.287 & 107 & 22.031 & 93 & 46.735 & 85 & -0.787 & 84 \\
\hline 4 & $\begin{array}{l}(\mathrm{AC}+\mathrm{HAp}) \text { of } \\
\text { Fish Bones }\end{array}$ & 1.591 & 58 & -63.317 & 80 & 74.642 & 76 & 2.096 & 58 \\
\hline
\end{tabular}

From Table 1 above, it is seen that Calcium and Activated Carbon from fish bones are effective in decreasing the rate of Lead $(\mathrm{Pb})$ inside the water. It is proven by some parameters in filter media when water treatment was conducted.

Table 2. The Test Result of Fish Bone Nutrition Facts with 15 Parameters

\begin{tabular}{|c|c|c|c|c|c|c|}
\hline No. & $\begin{array}{l}\text { Parameter } \\
\text { Test }\end{array}$ & $\begin{array}{l}\text { Unit of } \\
\text { Measure- } \\
\text { ment }\end{array}$ & $\begin{array}{l}\text { Result } \\
\text { Fishbone } \\
\text { Before } \\
\text { Treatment }\end{array}$ & $\begin{array}{l}\text { Result } \\
\text { Fishbone } \\
\text { After } \\
\text { Treatment }\end{array}$ & LOR & Test Method References \\
\hline 1 & Calories total & $\mathrm{kcal} / 100 \mathrm{~g}$ & 558.66 & 1000.69 & 0.01 & Calculation \\
\hline 2 & $\begin{array}{l}\text { Calories from } \\
\text { fat }\end{array}$ & $\mathrm{kcal} / 100 \mathrm{~g}$ & $<0.01$ & $<0.01$ & 0.01 & Calculation \\
\hline 3 & Fat total & $\mathrm{g} / 100 \mathrm{~g}$ & $<0.01$ & $<0.01$ & 0.01 & AOAC 996.06 \\
\hline 4 & Carbohydrate & $\mathrm{g} / 100 \mathrm{~g}$ & 26.99 & 57.85 & 0.01 & Calculation \\
\hline 5 & Protein & $g / 100 \mathrm{~g}$ & 6.37 & 1.92 & 0.01 & AOAC920.152 \\
\hline 6 & Sugar total & $\mathrm{g} / 100 \mathrm{~g}$ & $<0.01$ & $<0.01$ & 0.01 & In-House based on AOAC 925.05 \\
\hline 7 & $\begin{array}{l}\text { Dietary fiber } \\
\text { total }\end{array}$ & $\mathrm{g} / 100 \mathrm{~g}$ & 18.61 & 16.59 & 0.01 & AOAC985.29 \\
\hline 8 & Saturated Fat & $\mathrm{g} / 100 \mathrm{~g}$ & $<0.01$ & $<0.01$ & 0.01 & $\begin{array}{l}\text { In-House based on AOAC } 996.06 \& \text { \& } \\
\text { Operation Manual of Agilent } \\
\text { Technologies }\end{array}$ \\
\hline 9 & $\begin{array}{l}\text { Trans Fatty } \\
\text { Acid }\end{array}$ & $\mathrm{g} / 100 \mathrm{~g}$ & $<0.01$ & $<0.01$ & 0.01 & $\begin{array}{l}\text { In-House based on AOAC } 996.06 \text { \& } \\
\text { Operation Manual of Agilent } \\
\text { Technologies }\end{array}$ \\
\hline 10 & Cholesterol & $\mathrm{mg} / 100 \mathrm{~g}$ & $<0.01$ & $<0.01$ & 0.01 & $\begin{array}{l}\text { In-House Method based on Journal } \\
\text { of Food Composition \& Analysis } 16 \\
\text { (2003)147-153 }\end{array}$ \\
\hline 11 & $\begin{array}{l}\text { Vitamin AAS } \\
\text { Retinol } \\
\text { Acetate }\end{array}$ & $\mathrm{g} / 100 \mathrm{~g}$ & $<0.01$ & $<0.01$ & 0.01 & $\begin{array}{l}\text { In-House based on AOAC } 2002.06 \\
\text { by HPLC }\end{array}$ \\
\hline 12 & Vitamin C & $\mathrm{g} / 100 \mathrm{~g}$ & 0.51 & 0.06 & 0.01 & $\begin{array}{l}\text { In-House based on Report Analysis } \\
\text { of water soluble vitamin by HPLC }\end{array}$ \\
\hline 13 & Calcium $(\mathrm{Ca})$ & $\mathrm{g} / 100 \mathrm{~g}$ & 0.03 & 0.07 & 0.01 & $\begin{array}{l}\text { In-House method based on } \\
\text { AOAC } 999.08\end{array}$ \\
\hline 14 & Iron $(\mathrm{Fe})$ & $\mathrm{g} / 100 \mathrm{~g}$ & $<0.01$ & $<0.01$ & 0.01 & $\begin{array}{l}\text { In-House method based on } \\
\text { AOAC } 999.08\end{array}$ \\
\hline 15 & Sodium (Na) & $\mathrm{mg} / 100 \mathrm{~g}$ & 2.68 & 3.21 & 0.01 & $\begin{array}{l}\text { In-House method based on } \\
\text { AOAC } 999.08\end{array}$ \\
\hline
\end{tabular}


Table 3. The Analysis of Test Result from the Fish Bone Nutrition Facts with 15 Parameters

\begin{tabular}{|c|c|c|c|c|c|c|}
\hline \multirow[t]{2}{*}{ No. } & \multirow[t]{2}{*}{ Parameter Test } & \multirow{2}{*}{$\begin{array}{l}\text { Results } \\
\text { Before } \\
\text { Treatment }\end{array}$} & \multirow{2}{*}{$\begin{array}{c}\text { Results } \\
\text { After } \\
\text { Treatment }\end{array}$} & \multicolumn{2}{|c|}{$\begin{array}{c}\text { The Analysis Before and After } \\
\text { Treatment }\end{array}$} & \multirow[t]{2}{*}{ Notes } \\
\hline & & & & Value of change & $\%$ & \\
\hline 1 & Calories total & 558.66 & 1000.69 & 442.03 & $79.1 \approx 79$ & Increase \\
\hline 2 & Calories from fat & $<0.01$ & $<0.01$ & - & - & Stable \\
\hline 3 & Fat total & $<0.01$ & $<0.01$ & - & - & Stable \\
\hline 4 & Carbohydrate & 26.99 & 57.85 & 30.86 & $114.3 \approx 114$ & Increase \\
\hline 5 & Protein & 6.37 & 1.92 & 4.45 & $69.85 \approx 70$ & Decrease \\
\hline 6 & Sugar total & $<0.01$ & $<0.01$ & - & - & Stable \\
\hline 7 & Dietary fiber total & 18.61 & 16.59 & 2.02 & $10.85 \approx 11$ & Decrease \\
\hline 8 & Saturated Fat & $<0.01$ & $<0.01$ & - & - & Stable \\
\hline 9 & Trans Fatty Acid & $<0.01$ & $<0.01$ & - & - & Stable \\
\hline 10 & Cholesterol & $<0.01$ & $<0.01$ & - & - & Stable \\
\hline 11 & Vitamin & $<0.01$ & $<0.01$ & - & & Stable \\
\hline 12 & Vitamin C & 0.51 & 0.06 & 0.45 & $88.2 \approx 88$ & Decrease \\
\hline 13 & Calcium (Ca) & 0.03 & 0.07 & 0.04 & $133.3 \approx 133$ & Increase \\
\hline 14 & $\operatorname{Iron}(\mathrm{Fe})$ & $<0.01$ & $<0.01$ & - & - & Stable \\
\hline 15 & Sodium $(\mathrm{Na})$ & 2.68 & 3.21 & 0.53 & $19.7 \approx 20$ & Increase \\
\hline
\end{tabular}

From the nutrition fact test result on the fish bone powder, there were 15 parameters used before and after the treatment, as indicated in table 2 and 3. It is found that the rate of four ingredients increase respectively by $79 \%$ for Calori, $114 \%$ for Carbohydrate, $133 \%$ for Calcium and $20 \%$ for Sodium. While three ingredients decrease in rate: $70 \%$ for Protein, $11 \%$ for Dietary Fibers and $88 \%$ for Vitamin C. On the other side, eight organic ingredients show stable rate: calori, fat calori, sugar, saturated fat, trans fatty acid, cholestherol, and AAS vitamin rethinyl acetate and iron.

Table 4. X-RF Test on Fish Bone Sample

\begin{tabular}{ccc}
\hline No. & Compound & Count Unit (\%) \\
\hline 1. & $\mathrm{P}$ & 12.20 \\
2. & $\mathrm{~S}$ & 0.59 \\
3. & $\mathrm{~K}$ & 0.2 \\
4. & $\mathrm{Ca}$ & 85.41 \\
5. & $\mathrm{Mn}$ & 0.087 \\
6. & $\mathrm{Fe}$ & 0.19 \\
7. & $\mathrm{Cu}$ & 0.082 \\
8. & $\mathrm{Zn}$ & 0.17 \\
9. & $\mathrm{Sr}$ & 0.58 \\
10. & $\mathrm{Yb}$ & 0.45 \\
11. & $\mathrm{Re}$ & 0.07 \\
\hline
\end{tabular}

It is seen from Table 4 and Figure 2 that X-RF test was conducted on fish bone sample and it is concluded that fish bones contain calcium with approximately $85.41 \%$ count unit. 


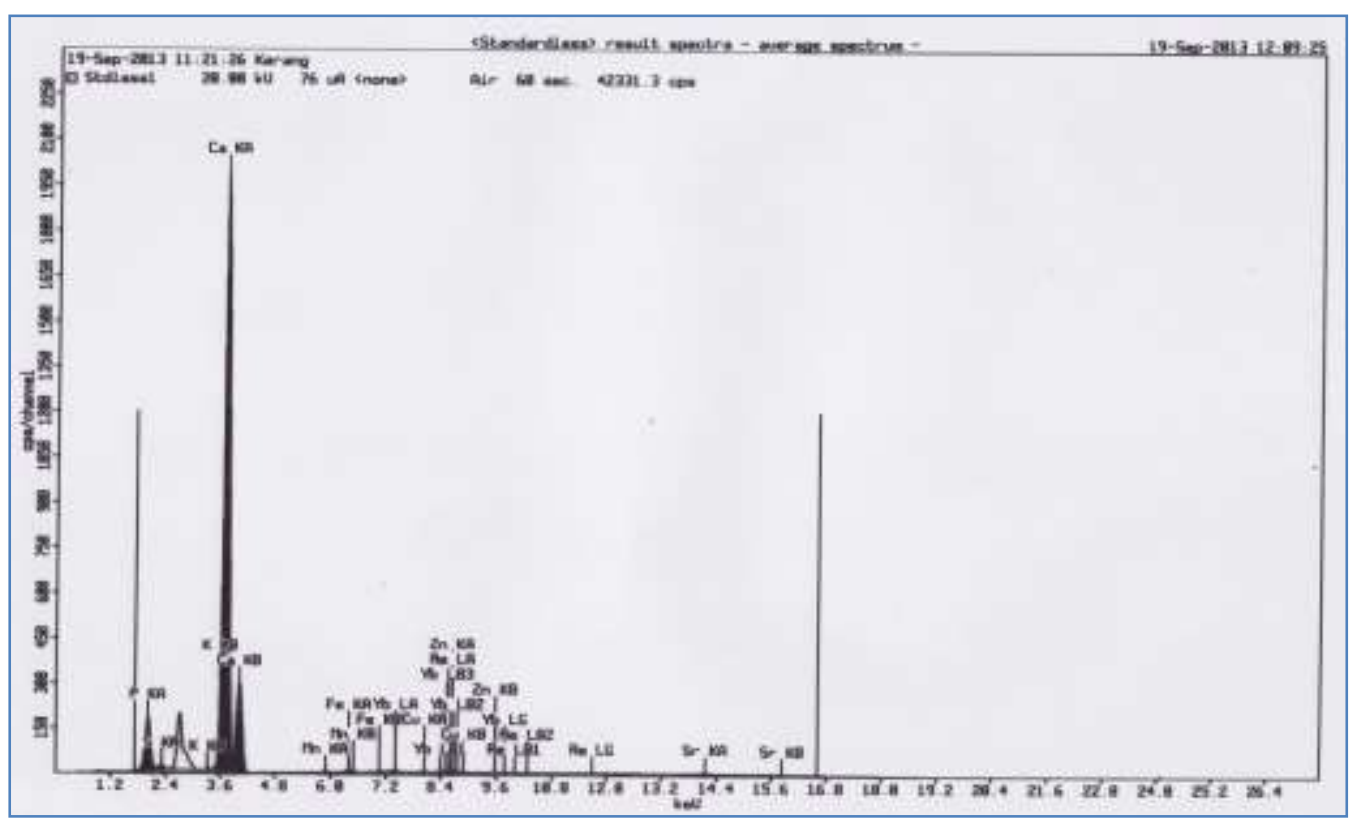

Figure 2. X-RF Chart of Fish Bone

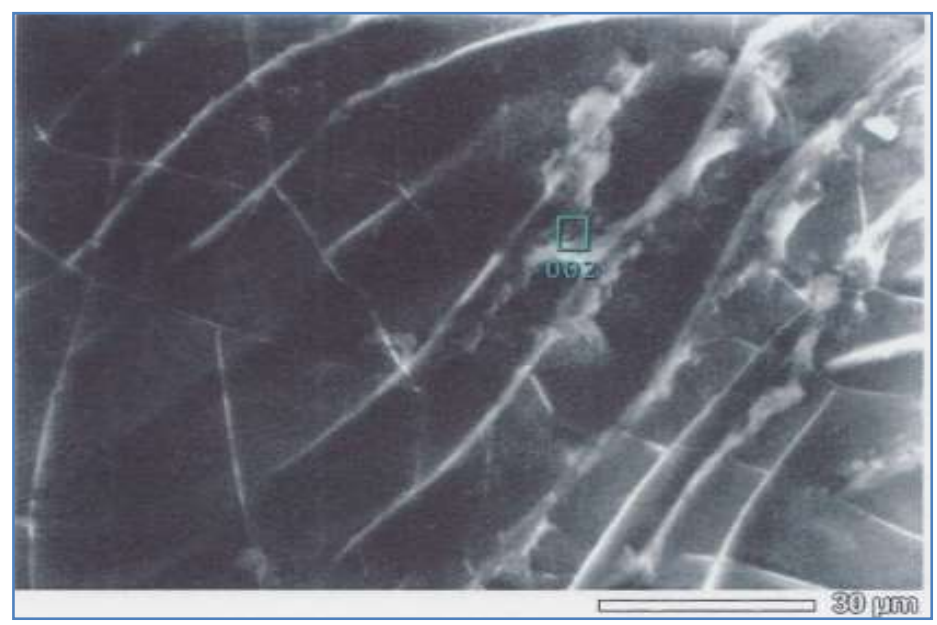

Figure 3. SEM Result of Fish Bones

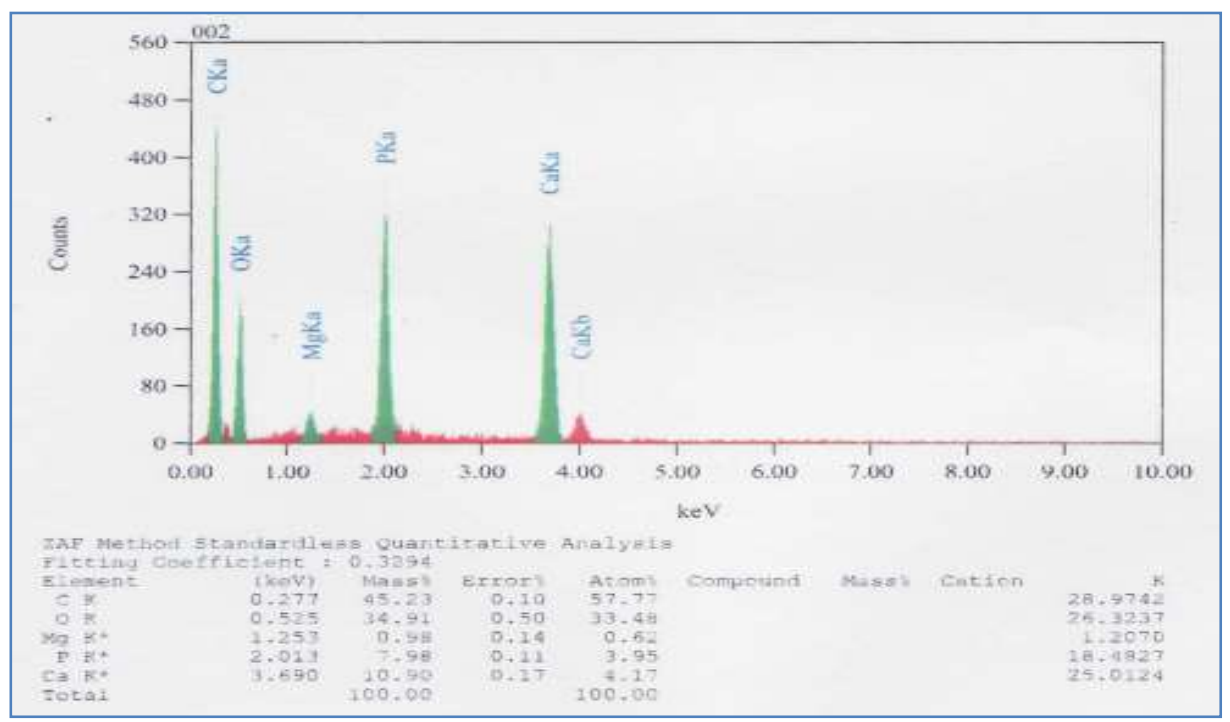

Figure 4. EDS Result of Fish Bones at UPM Malaysia 
Based on the SEM EDS test on the fish bones, it is concluded that there is calcium (Ca) contained in the spot $\mathrm{Ca} \mathrm{K}+3,690(\mathrm{keV})$ with mass percentage of $10.90(\%)$ and atom $4.17(\%)$, also on $\mathrm{K}$ position by 25.0124 .

\section{Conclusion}

The transfer of knowledge and technology to people in coastal areas have resulted products made of the fish bone waste. The approach was done with social purpose, specifically for economic empowerment towards the pre-commercial and commercial process of the products (business oriented). Economically speaking, this program is able to realize a new industry with the use of good and organic materials. The calcium products, which are currently made of chemical materials, can be replaced by the organic calcium products made of fish bone waste. Through this program, the university hopes to empower the people in coastal community. Based on the quantitative data through characterization test, it is proven that the fish bones potentially contains high calcium, for which it is able to act as the water filter to clean the polluted water. Thus the water will meet the quality standard for drinking.

\section{Acknowledgement}

To Universiti Malaysia Terengganu and The Ministry of Science and Technology of Malaysia for the assistance in Knowledge Transfer Program Scheme Grant, processing the fish bone waste into the organic calcium products which then produced the prototype of filter media for the drinking water at coastal community.

\section{REFERENCES}

[1] D. Aisyah, I. Mamat, M. Sontang, M. A. A.N and Nurhayati, "Program Libatsama Pengurusan Sisa Tulang Ikan untuk Produk Hidroksiapatit: Kajian di Komuniti Pemproses Keropok Kuala Trengganu-Malaysia," Kuala Trengganu, Malaysia, 2013.

[2] D. Aisyah, I. Mamat, M. Sontang, Z. Rosufila and N. M. Ahmad, "Program Pemanfaatan Sisa Tulang Ikan untuk Produk Hidroksiapatit: Kajian di Pabrik Pengolahan Kerupuk Lekor Kuala Trengganu-Malaysia," Jurnal Sosioteknologi, vol. 11, no. 26, pp. 129-141, 2012.

[3] Mutmainnah, S. Chadijah and W. O. Rustiah, "Hidroksiapatit dari Tulang Ikan Tuna Sirip Kuning (Tunnus albacores) dengan Metode Presipitasi," Al-Kimia, vol. 5, no. 2, pp. 119126, 2017.

[4] Anderson and et al, "Upwelling and fish factory waste as nitrogen sources for suspended cultivation of Gracilaria gracilis in Saldanha Bay. South Africa," Hydrobiologia, vol. 398/399, pp. 455-462, 1999.

[5] Laufenberg and et al, "Transformation vegetable waste into value added products," Biotechnol, vol. 22, p. 67-71, 2003.

[6] I. Mamat, D. Aisyah, M. Sontang, Z. Rosufila and N. M. Ahmad, "Fish Bone Utilization Program for Hydroxyapatite Product: a Case Study of Knowledge Transfer from a University to Coastal Communities," Journal of Environmental Research \& Development , vol. 7, no. 3, pp. 1274-1281, 2013.

[7] T. Yin and et al, "Preparation and characterization of ultrafine fish bone powder," Journal of Aquatic Food Product Technology, vol. 25, no. 7, pp. 1045-1055, 2016. 
[8] Venkatesan, Jayachandran and S.-K. Kim, Marine biomaterials. Springer Handbook of Marine Biotechnology, Berlin, Heidelberg: Springer, 2015, pp. 1195-1215.

[9] Y. Mu, A. Salfarzadeh, Saffarzadeh and T. Shimaoka, "Utilization of waste natural fishbone for heavy metal stabilization in municipal solid waste incineration fly ash," Journal of cleaner production, vol. 172, pp. 3111-3118, 2018.

[10] V. Lalzawmliana and etal, "Marine organisms as a source of natural matrix for bone tissue engineering," Ceramics International, 2018.

[11] A. T. Sulistiyani, D. Aisyah, I. Mamat and M. Sontang, "Pemberdayaan Masyarakat Pemanfaatan Limbah Tulang Ikan untuk Produk Hidroksiapatit (Hydroxyapatite/HA) Kajian di Pabrik Pengolahan Kerupuk Lekor Kuala Terengganu Malaysia," Jurnal Pengabdian Kepada Masyarakat, Vols. 14-29, no. 1, p. 2, 2016.

[12] S. Pembaruan, "mellidotorg.wordpress.com," 23 March 2007. [Online].

[13] A. Komarulzaman, J. Smits and E. d. Jong, "Clean water, sanitation and diarrhoea in Indonesia: Effects of household and community factors," Global public health, vol. 12, no. 9, pp. 1141-1155, 2017.

[14] A. A. Yusuf and B. P. Resosudarmo, "Does clean air matter in developing countries' megacities? A hedonic price analysis of the Jakarta housing market, Indonesia," Ecological Economics, vol. 68, no. 5, pp. 1398-1407, 2009.

[15] M. N. Suin, "Dampak Pencemaran pada Ekosistem Pengairan," in Prosiding Penataran Pencemaran Lingkungan Dampak dan Penanggulangannya Pemda Kodya TK II. , Padang, 1994.

[16] D. Zairion, "Dampak Pembangunan Terhadap Biota Air. Makalah Kursus AMDAL," IPB, Bogor, 2003.

[17] M. Irwan, A. Alianto and Y. T. Toja, "Physical Chemical Condition of Rivers in Sawaibu Bay of Manokwari Regency," Jurnal Sumberdaya Akuatik Indopasifik, vol. 1, pp. 81-92, 2017.

[18] K. M. N. KLH, "Pedoman Baku Mutu Lingkungan. Nomor Kep-02. MENKLH/I/1988," Sekretariat Menteri Negara Kependudukan dan Lingkungan Hidup, Jakarta, 1988.

[19] O. D. Parung, M. Litaay and E. Johannes, "Analisis Kandungan Timbal (Pb) pada Sedimen, Air Laut dan Kerang Darah (Anadara granosa L.) di Perairan Pesisir Makassar," Jurnal Marina Acta Chimica, pp. 1-10, 2015.

[20] D. Martaningtyas, Bahan Cemaran Logam Berat, Jakarta: Cakrawala, 2004. 